\title{
Analysis of cognitive disorders in older people with diabetes - preliminary study
}

\section{Analiza zaburzeń procesów poznawczych u osób starszych z cukrzyca - badania wstępne}

\author{
Aneta Kozieł', Monika Pierzak', Martyna Wychowaniec ${ }^{1}$, Stanisław Głuszek ${ }^{2,3}$ \\ 'Doctoral Studies, Faculty of Medicine and Health Sciences, Jan Kochanowski University, Kielce, Poland \\ Head of the Faculty: Prof. Stanisław Głuszek MD, PhD \\ ${ }^{2}$ Department of Surgery and Surgical Nursing with Research Laboatory, Institute of Medical Sciences, Faculty of Medicine \\ and Health Science, Jan Kochanowski University, Kielce, Poland \\ Head of the Department: Prof. Stanisław Głuszek MD, PhD \\ ${ }^{3}$ Clinical Department of General, Oncological and Endocrinological Surgery, Regional Hospital, Kielce, Poland \\ Head of the Department: Prof. Stanisław Głuszek MD, PhD
}

Key words: diabetes mellitus, mild cognitive disorders, elderly people.

Słowa kluczowe: cukrzyca, łagodne zaburzenia poznawcze, osoby starsze.

\begin{abstract}
Introduction: Diabetes is a growing public health problem. Epidemiological studies indicate that the disease shortens life and significantly deteriorates its quality. The impact of diabetes on physical health of patients is well documented, but its impact on cognitive abilities has not been studied in detail so far. The deficit of reports regarding this problem among Polish researchers was an inspiration to start new studies.

Aim of the research: To evaluate mild cognitive disorders in elderly patients with diabetes.

Material and methods: The study was conducted in 2015. The study group included 7 elderly people with type 2 diabetes for more than 10 years. The control group consisted of 7 individuals of the same age without diabetes. The research tool was a self-made questionnaire to examine the cognitive abilities. An analysis of cognitive functions such as short-term memory, performing analysis and synthesis processes, understanding and creating metaphorical examples, narration and performing metalinguistic operations was performed.

Results: Differences in cognitive functioning in the field of the studied variables were observed between examined groups. Elderly people with diabetes achieved significantly lower scores in all examined cognitive functions than healthy respondents. Conclusions: Elderly patients with type 2 diabetes are particularly susceptible to mild cognitive impairment. It is necessary to take this group of patients under diagnosis and early secondary prevention in order to prevent the negative impact of the disease.
\end{abstract}

\section{Streszczenie}

Wprowadzenie: Cukrzyca stanowi narastający problem zdrowia publicznego. Badania epidemiologiczne wskazuja, że choroba ta skraca życie i w znacznym stopniu pogarsza jego jakość. W opracowaniach dość dobrze opisane jest oddziaływanie cukrzycy na stan somatyczny pacjentów, jednak wpływ tej choroby na funkcjonowanie poznawcze człowieka nie był dotąd szczegółowo badany. Deficyt doniesień w zakresie omawianej tematyki na gruncie polskiej gerontologopedii stał się inspiracją do podjęcia badań.

Cel pracy: Ocena łagodnych zaburzeń poznawczych u osób w podeszłym wieku chorujących na cukrzycę.

Materiał i metody: Badanie przeprowadzono w 2015 r. w grupie 7 starszych osób chorujących minimum 10 lat na cukrzycę typu 2. Grupę kontrolną stanowiło 7 osób w tym samym wieku bez cukrzycy w wywiadzie. Narzędziem badawczym był kwestionariusz do badania funkcji poznawczych własnej konstrukcji. Przeprowadzono analizę funkcji poznawczych, takich jak: pamięć krótkotrwała, dokonywanie procesów analizy i syntezy, rozumienie i tworzenie znaczeń metaforycznych, narracji oraz dokonywanie operacji metajęzykowych.

Wyniki: Zaobserwowano różnice $\mathrm{w}$ funkcjonowaniu poznawczym między pacjentami z grup objętych badaniem w zakresie mierzonych zmiennych. Osoby starsze z cukrzycą osiągają znacząco niższe wyniki we wszystkich badanych funkcjach poznawczych niż zdrowi respondenci.

Wnioski: Osoby w podeszłym wieku z rozpoznaną cukrzycą typu 2 są szczególnie podatne na występowanie łagodnych zaburzeń poznawczych. Konieczne jest objęcie tej grupy diagnostyką i wczesną profilaktyką wtórną w celu zapobiegania utrwalaniu się niekorzystnych następstw choroby. 


\section{Introduction}

Diabetes is a growing public health problem. Epidemiological studies show that this disease shortens life and, to a large degree, deteriorates its quality in the physical, emotional, and social aspects. In the literature, the effect of diabetes on the somatic state of patients has been relatively well described; however, until today, its effect on human cognitive functioning has not been investigated in detail, and mainly psychologists and neurologists deal with this problem. To date, no reports have been encountered in Polish literature concerning the effect of cognitive disorders on linguistic functions.

At present, diabetes is a common and very serious social problem, due to the increasing number of diabetic patients, as well as health and social difficulties associated with the occurrence of later complications [1]. It is not defined as one disease, but as a group of metabolic disorders characterized by chronic hyperglycaemia resulting from disturbed insulin secretion or action. Chronic hyperglycaemia in diabetes is related to impairment, disturbance in functioning and insufficiency of various organs, especially the eyes, kidneys, nerves, heart and blood vessels [2]. Diabetes has a considerable negative effect on the central nervous system. This disease often takes a clinically silent course.

Analysis of the effect of diabetes on cognitive functioning is important considering several factors. A decrease in the efficiency of cognitive functions may result in worse diabetes control and, in consequence, intensify its symptoms. Patients with more severe cognitive deficits may have difficulties with understanding and following doctors' recommendations, or even more frequent need of assistance from third parties during daily activity. It seems very important to monitor cognitive functioning, not only at the time of making the diagnosis, but also at subsequent stages of the disease, because this may considerably improve the possibility of undertaking adequate prophylactic actions [3].

Patients with diabetes are characterized by an accelerated ageing process. Therefore, in this group of patients, more frequent occurrence of cognitive function disorders directly related to biological age should be expected [4].

The first reports concerning the effect of diabetes on intellectual functions were published by Miles and Root in 1922 [5], where the researchers paid attention to deterioration of memory, weakening of arithmetic skills, and psychomotor inefficiency in diabetic patients [6]. Diabetes causes a two-fold increase in the probability of occurrence of dementia, both angiogenic, and that developing as a result of Alzheimer's disease [7, 8]. Cukierman et al. [9] proposed classifying the decline in cognitive efficiency in the group of chronic diabetes complications.

\section{Aim of the research}

The objective of the present study was to assess mild cognitive disorders in elderly patients with diabetes.

\section{Material and methods}

The study included older patients aged 60-70, who had had type 2 diabetes for a minimum of 10 years. The adopted criterion of enrolment resulted from analysis of the literature which constituted the theoretical basis of the study, which proves that in individuals within this age interval the disorders of cognitive functions are most clear, and the clinical image is not blurred by the possibility of occurrence of dementia. The exclusion criterion for participation in the study was the lack of logical contact with patients, neurological disorders, mental disorders, and cardiovascular diseases at the stage of inefficiency. Ultimately, the study group included 7 patients at an older age: 3 women and 4 men. The study was conducted in a residential home. The mean age of patients was $66 \pm$ 3.46 (minimum 60, maximum 70).

The largest group of patients had primary school education (42.86\%), followed by secondary school education (42.86\%), and only one person had vocational education (14.28\%).

The control group for diabetic patients was a group of 7 persons with no diabetes or chronic diseases in medical history taking, also living in the residential home; 3 were female and 4 male; mean age was $65.14 \pm 3.71$ (minimum 60, maximum 70). The largest number of respondents from the control group had a secondary school education $(42.86 \%)$, followed by vocational (28.57\%), and primary education (28.57\%).

The research instrument was a questionnaire for the investigation of cognitive functions designed by the author. It consisted of 5 main sub-tests, while each sub-test contained individual blocks of tasks. Analysis of cognitive functions such as short-term memory (visual and auditory), analysis and synthesis (visualletter, phonemic, mental), metaphorical meanings (understanding of comparative expressions and phraseological expressions, use of comparative expressions and phraseological expressions), narration (understanding and creation of narrative statements), and metalingual operations (categorization, synonymics, antonymics, defining) was performed.

\section{Results}

Both in the group of patients with diabetes and the group of older controls without diabetes worse results were obtained with respect to the functioning of short-term auditory memory, and better results in short-term visual memory; however, the group of patients with diabetes obtained worse results. It was found that diabetes deteriorates primarily short-term 
auditory memory; but, to a considerable degree, it also decreases visual-spatial functions, as well as shortterm visual memory. Short-term memory disorders are inseparably connected with a decline in concentration skills and deterioration of attention, which was confirmed by the results of tasks concerning memorization of information, presented in illustration and verbal material (Figure 1).

With respect to short-term visual memory, the most difficult for the study group was the task in which respondents had to memorize words in appropriate gaps. The study group obtained 23\% and the control group 59\% correct answers in this task. The easiest task was the memorization of sequences of numbers. In this task, the study group obtained $67 \%$ and the control group 76\% correct answers.

Older patients with diabetes had no problems with short-time memorization of sequences of numbers and few difficulties with memorization of surnames of persons; nevertheless, they had considerable difficulties with respect to recalling geometric material, memorization of details in photographs and read text, and memorization of words in a sequence. These difficulties may be caused by decreased skills of concentration on a large number of visual stimuli, both in illustration and word material.

Considering short-term auditory memory, the task consisting in memorization of surnames by ear was more difficult for both groups than the task consisting in memorization of details in read texts. Diabetic patients have more difficulties with auditory than visual perception (Figure 2).

In the task concerning memorization of details in listening texts, the patients from the study group achieved considerably lower results, compared to the control group. The low result indicates that older persons with diabetes have problems with concentration on details in a listening text and, therefore, they memorize a smaller amount of information, compared to the control group. It was observed that the longer the text, the smaller the number of details memorized by diabetic patients. Comparing the results in the study group, they obtained better results in read than listening texts.

Figure 3 presents the summing up of visual-letter analysis and synthesis, phonemic analysis and synthesis, and mental analysis and synthesis.

Both for the study and control groups, visual-letter synthesis was the most difficult, whereas visual-letter analysis was the easiest. The respondents' difficulties with respect to the processes of analysis and synthesis resulted primarily from disorders in concentration, disorders in attention divisibility, disorders in auditory and visual perception, as well as with literal understanding of texts and aphorisms.

Summing up the results of examination of understanding and use of comparative and phraseological expressions, it was found that in the study group the

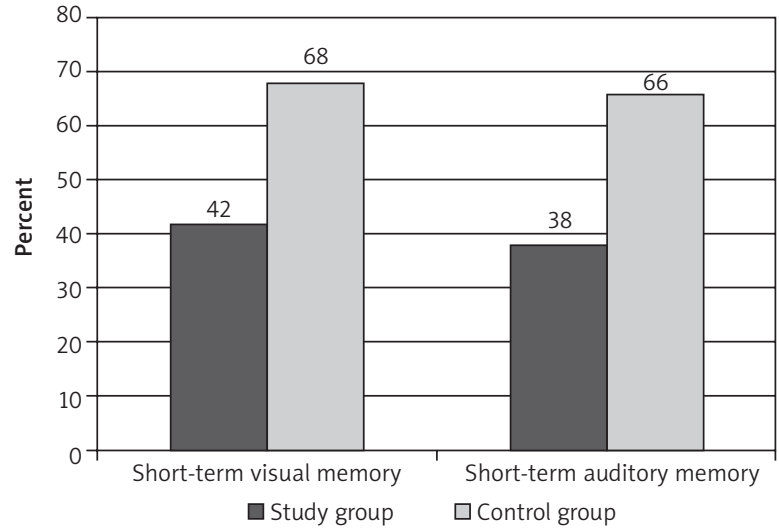

Figure 1. Short-term memory - summary of results obtained in the study and control groups

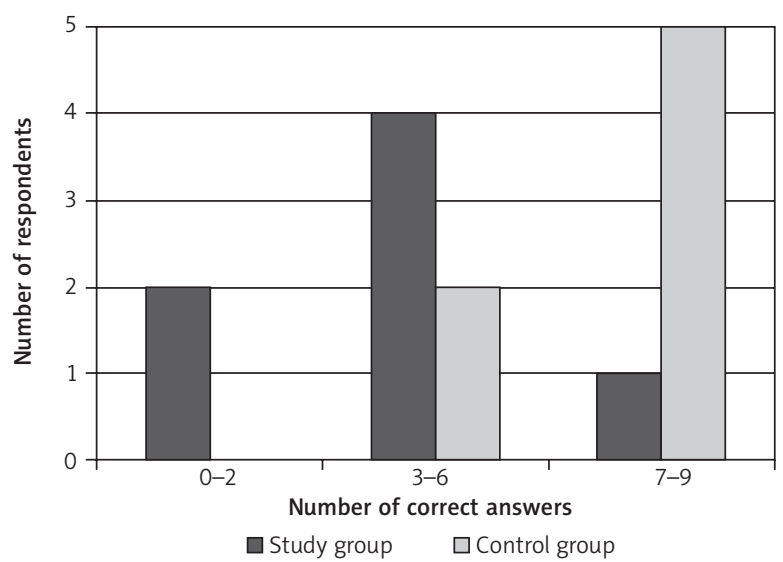

Figure 2. Short-term auditory memory - comparison of the sum of correct answers in the task concerning memorization of details in listening texts by the study and control groups

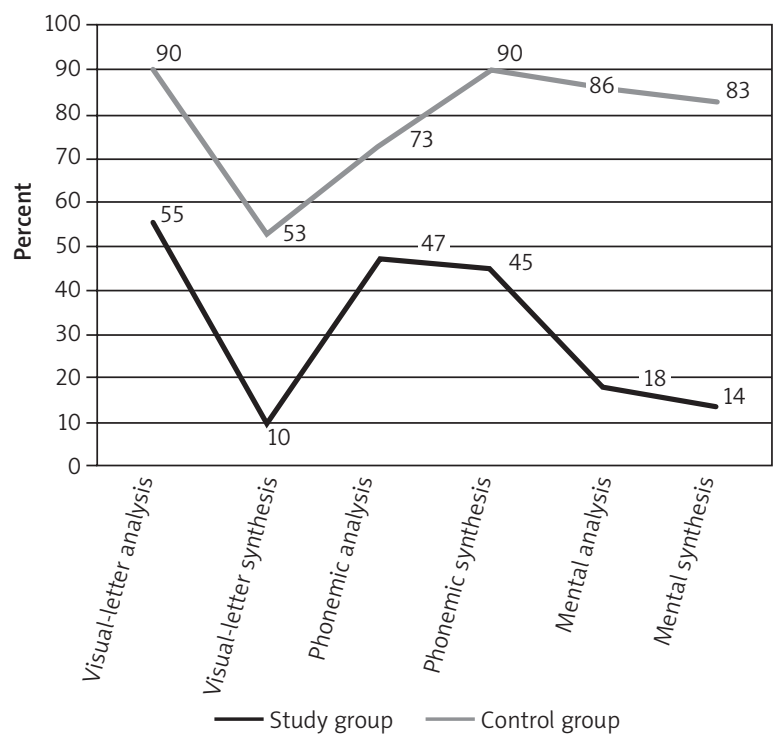

Figure 3. Comparison of the results of investigation of the processes of analysis and synthesis obtained by the study and control groups 
respondents obtained lower results with respect to understanding comparative and phraseological expressions, whereas in the control group worse results concerned the use of comparative and phraseological expressions.

Errors in understanding of comparative and phraseological expressions by the respondents consisted mainly in reporting literal, not metaphorical meanings. It also happened that the patients explained descriptively 'what can be done with something' or 'about whom something is being said', but without explaining the meaning of the phraseological expression.

The research group obtained significantly lower results with respect to understanding narration, compared to the control group. This mainly resulted from attention disorders in older patients with diabetes. These errors might have been caused by decreased concentration, as well as short-term memory disorders.

The graph illustrating the percentage of correct answers in all spheres presents the summing up of all the investigated metalingual operations: categorization (indication of elements from outside the class or combining elements into classes), synonymics (understanding and formulation of synonyms), antonymics (understanding and formulation of antonyms), and defining (understanding and formulation of definitions) (Figure 4).

Considering the performance of metalingual operations, the study group made many mistakes, caused mainly by decreased verbal fluency, both with respect to categories and words, antonyms and synonyms.

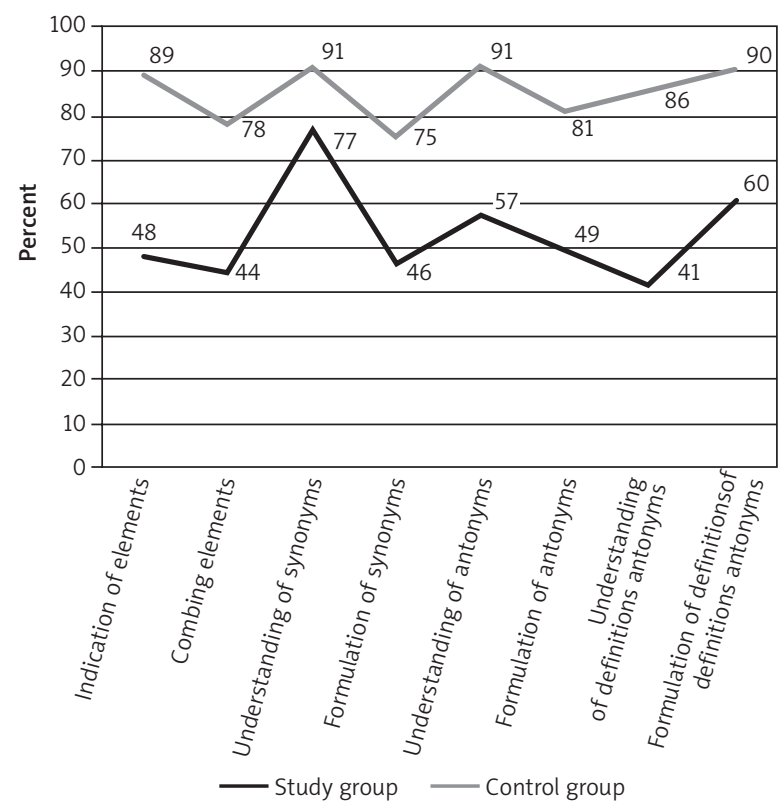

Figure 4. Comparison of results of investigations of metalingual operations obtained by the study and contro groups
The respondents also compensated their lingual shortcomings by defining synonyms and antonyms descriptively. In turn, in categorization, they had no skills of perceiving detailed categories, and only reported superior categories. The definitions mentioned by the study group were considerably less abundant in contents, less precise, and incomplete, compared to the control group.

\section{Discussion}

Despite considerable progress in the treatment of diabetes, it still remains an important clinical problem. Therefore, an improvement in the medical care of diabetic patients should be the prime goal in modern diabetology. The correct treatment of patients may prevent or delay the occurrence of many consequences, including cognitive disorders.

Analysis of the results of the present study revealed worse cognitive functioning of patients with diabetes, compared to the control group. Such results were also obtained by other researchers investigating this problem [4, 10-12], who observed that diabetes exerts a negative effect on the cognitive efficiency of patients. According to Lobnig et al. [13], there are small differences in cognitive functioning with respect to both types of diabetes, compared to the group of healthy individuals. Also, Hsu-Ko et al. [14] reported a general slowing down in the thinking processes in diabetic patients. In the group of individuals aged over 60, as early as 4 years after diagnosing the disease, a significant decrease was observed with respect to cognitive efficiency, compared to healthy individuals [15].

Type 2 diabetes causes disorders concerning verbal and spatial memory, effectiveness of attention processes, verbal fluency, functions dependent on the frontal lobe, mainly matching functions, and psychomotor skills [16, 17]. The results of the present study indicate that the respondents had more difficulties with tasks concerning short-term auditory memory than short-term visual memory. The study confirmed that diabetes considerably deteriorates the persistence of attention and concentration. Diabetic patients obtain considerably lower results in the area of cognitive functions, compared to healthy individuals, including executive functions, visual-spatial operational memory, mental analysis and synthesis, psychomotor speed, concentration and divisibility of attention, as well as the effectiveness of learning [18]. A significant decline in operational memory, selectiveness of attention, psychomotor speed and analysis of complex information was confirmed in patients with diabetes, compared to the control group of healthy individuals $[19,20]$. Kozub-Doros et al. [21] found a considerable effect of metabolic disorders on the nervous system, as well as the necessity for considering the monitoring of cognitive functions in the care of diabetic patients. Pasquier et al. [11] additionally described a decline in 
the effectiveness of executive functions in this group of patients. This observation was also confirmed in the present research material. With respect to the result of efficiency of abstract thinking, older individuals showed disorders in understanding comparative and phraseological expressions. The results of investigation of metalingual operations indicated that patients with diabetes had difficulties with combining elements into classes, formulation of synonyms, formulation of antonyms, and understanding definitions. Considering all metalingual operations, the tasks concerning the understanding of definitions proved to be most difficult. Also, the respondents obtained worse results in the understanding of narration than in its creation. The study group obtained almost ten-fold lower results with respect to understanding narration, compared to the control group. With respect to the processes of analysis and synthesis the following were compared: visual-letter analysis and synthesis, phonemic analysis and synthesis, and mental analysis and synthesis. Patients with diabetes obtained the lowest results in the area of visual-letter synthesis, phonemic synthesis, and mental synthesis. A considerable difference between the results obtained by both groups was observed in the sphere of mental analysis and synthesis. The study group obtained nearly five-fold lower results in the area of mental analysis, and nearly six-fold lower results in mental synthesis, compared to the control group. Visual-letter synthesis was the most difficult for both the study and control groups.

Frequently, mild cognitive disorders have the character of discrete changes, disguised by the patient by using mechanisms which compensate for the shortcomings. During the study, it was observed that patients, when asked to repeat a command, provided wrong answers, even when they became aware of it, in order to disguise deficits. Patients, when having difficulties with reporting specific names of objects, tried to describe them.

It is noteworthy that, in the review of literature to date, no reports have been found concerning the effect of diabetes on understanding and formulation of metaphorical meanings, nor detailed studies of the processes of analysis and synthesis, which would considerably expand the understanding of disorders related to diabetes.

However, the results of studies pertaining to the effect of diabetes on the efficiency of cognitive processes are not unequivocal. Some researchers question the intensification of cognitive disorders in the group of patients with diabetes, compared to the control group [22]. Analysis of the literature shows that in 6 out of 11 studies comparing the functioning of cognitive processes using screening tests, no statistically significant differences were found between the groups of diabetic patients and the groups of healthy individuals [17]. The relationship between diabetes and cognitive func- tion disorders is complex and complicated [19, 20]. Kurzawa et al. [4] emphasized that low education level, life in a rural environment, and loneliness considerably affect the occurrence of cognitive disorders. Also, Kozub-Doros et al. [21] observed that an unfavourable effect of diabetes on cognitive functions is found especially in individuals with a low education level and in older age. A low level of education may explain the more frequent occurrence of cognitive disorders in the group of patients with diabetes. It is known that a higher 'cognitive reserve' is related to a higher education level, because it provides the possibility of constant expansion of the resources of knowledge [22, 23]. In the present study, the respondents constituted a relatively homogeneous group according to education, but due to the small size of the group and lack of statistical confirmation of results, it is difficult to conclude the effect of respondents' education on their answers. The present study has the character of a preliminary report, and indicates the need for more comprehensive studies concerning cognitive function disorders in older patients with diabetes.

\section{Conclusions}

Type 2 diabetes, overlapping with changes related to the ageing processes, causes acceleration in the occurrence of mild cognitive disorders in this group of patients. This is especially important in the context of the necessity for self-care in diabetes, dosing of drugs, maintenance of adequate diet, and compliance with medical recommendations aimed at good control of glycaemia. Implementation of early diagnostics provides the possibility to apply appropriate neurological, psychological, and logopaedic therapy. The work of a speech therapist should aim at improvement of understanding of longer verbal commands, metaphors, aphorisms, development of verbal fluency, as well as supporting executive functions, such as formulation of concepts, abstract thinking, categorization, and concluding.

\section{Conflict of interest}

The authors declare no conflict of interest.

\section{References}

1. Zimmet P, Alberti K.G, Shaw J. Global and societal implications of the diabetes epidemic. Nature 2001; 414: 782-7.

2. http://apps.who.int/iris/bitstream/10665/41399/1/WHO_ TRS_646.pdf

3. Talarowska M. Zaburzenia funkcji poznawczych w chorobach psychicznych i somatycznych. In: Podstawy psychologii. Podręcznik dla studentów medycyny i kierunków medycznych. Talarowska M, Florkowski A, Gałecki P (eds). Continuo, Wrocław 2011; 141-3.

4. Kurzawa J, Zozulińska D, Wierusz-Wysocka B. Ocena występowania zaburzeń funkcji poznawczych u chorych na cukrzycę. Diabetol Prakt 2004; 5: 255-60. 
5. Miles WR, Root HF. Psychologic tests applied to diabetic patients. Arch Intern Med 1922; 30: 767-77.

6. Pierzchała K, Kozub-Doros I. Funkcje poznawcze u chorych na cukrzycę. Diabetol Dośw Klin 2005; 5: 93-6.

7. Ott A, Stolk R, van Harskamp F, Pols H, Hofman A, Breteler M. Diabetes mellitus and risk of dementia. The Rotterdam study. Neurology 1999; 53: 19-37.

8. Arvanitakis Z, Wilson RS, Bienias JL, Evans DA, Bennett DA. Diabetes mellitus and risk of Alzheimer disease and decline in cognitive function. Arch Neur 2004; 61: 661-7.

9. Cukierman T, Gerstein H, Williamson JD. Cognitive decline and dementia in diabetes - systematic overview of prospective observational studies. Diabetologia 2005; 48: 2460-9.

10. Kanaya A, Barrett-Connor E, Gildengorin G, Yaffe K. Change in cognitive function by glucose tolerance status in older adults: a 4-year prospective study of the Rancho Bernardo study cohort. Arch Intern Med 2004; 164: 1327-33.

11. Pasquier F, Boulogne A, Leys D, Fontaine P. Diabetes mellitus and dementia. Diabetes Metab 2006; 32: 403-14.

12. Van Harten B, Oosterman J, Muslimovic D, van Loon BJ, Scheltens P, Weinstein HC. Cognitive impairment and MRI correlates in the elderly patients with type 2 diabetes mellitus. Age Ageing 2007; 36: 164-70.

13. Lobnig B, Krömeke O, Optenhostert-Porstt C. Hippocampal volume and cognitive performance in long-standing type 1 diabetic patients without macrovascular complications. Diabet Med 2005; 23: 32-9.

14. Hsu-Ko K, Jones R, Milberg W. Effect of blood pressure and diabetic mellitus and cognitive and physical functions in older adults: a longitudinal analysis of the advanced cognitive training for independent and vital elderly cohort. J Am Geriatr Soc 2005; 53: 1154-61.

15. Fontbonne A, Berr C, Ducimetiere P. Changes in cognitive abilities over a 4-year period are unfavorably affected in elderly diabetic subjects: results of the epidemiology of vascular aging study. Diabetes Care 2001; 24: 366-70.

16. Arvanitakis Z, Wilson RS, Li Y, Aggarwal NT, Bennett DA. Diabetes and function in different cognitive systems in older individuals without dementia. Diabetes Care 2006; 29: 560-6.

17. Awad N, Gagnon M, Messier C. The relationship between impaired glucose tolerance, type 2 diabetes, and cognitive functions. J Clin Exp Neuropsychol 2004; 26: 1044-80.

18. Talarowska-Bogusz M, Florkowski A, Zboralski K, Orzechowska A, Gałecki P. Funkcjonowanie poznawcze u chorych na cukrzycę typu 1 oraz typu 2 - doniesienia wstępne. Psychiatr Prakt Ogólnolek 2007; 7: 51-59.

19. Derkacz M, Marczewski K. Cukrzyca a zaburzenia funkcji kognitywnych. Pol Arch Med Wewn 2005; 113: 273-7.

20. Derkacz M, Sawicka A, Marczewski K. Łagodne zaburzenia funkcji poznawczych u chorych na cukrzycę - obserwacje ośrodka terenowego. Diabetol Dośw Klin 2005; 5: 273-8.

21. Kozub-Doros I, Pierzchała K, Łabuz-Roszak B, Strojek K. Ocena funkcji poznawczych u chorych na cukrzycę. Diabetol Dośw Klin 2010; 10: 46-52.

22. Kokoszka A, Kot W. Związek wieku pacjenta z intensywnością leczenia cukrzycy typu 2. Pol Arch Med Wewn 2007; 117: 1-5.

23. Bilikiewicz A, Barcikowska M, Kądzielawa D, Kotapka-Minc S, Leszek J, Mossakowski M, Opala G, Parnowski T,
Pfeffer A, Szczudlik A, Zakowska-Wachelko B. Wczesne rozpoznawanie i leczenie otępienia typu Alzheimera. Stanowisko interdyscyplinarnej grupy ekspertów rozpoznawania (i leczenia) otępień, IGERO. MAKmed, Gdansk 1999.

\section{Address for correspondence:}

\section{Aneta Kozieł MD}

Faculty of Medicine and Health Science

Jan Kochanowski University

al. IX Wieków Kielc 19, 25-317 Kielce, Poland

Phone: +48 693716969

E-mail: anetak8@gmail.com 